\title{
Patterns in Nature-S-Layer Lattices of Bacterial and Archaeal Cells
}

\author{
Dietmar Pum $^{1, *(\mathbb{D})}$, Andreas Breitwieser ${ }^{1}(\mathbb{D})$ and Uwe B. Sleytr ${ }^{2}$ \\ 1 Department of Nanobiotechnology, Institute of Biophysics, University of Natural Resources and Life Sciences \\ Vienna, Muthgasse 11, 1190 Vienna, Austria; andreas.breitwieser@boku.ac.at \\ 2 Department of Nanobiotechnology, Institute of Synthetic Bioarchitectures, University of Natural Resources \\ and Life Sciences Vienna, Muthgasse 11, 1190 Vienna, Austria; uwe.sleytr@boku.ac.at \\ * Correspondence: dietmar.pum@boku.ac.at; Tel.: +43-1-47654-80360
}

Citation: Pum, D.; Breitwieser, A.; Sleytr, U.B. Patterns in NatureS-Layer Lattices of Bacterial and Archaeal Cells. Crystals 2021, 11, 869. https://doi.org/10.3390/ cryst11080869

Academic Editor: Christopher D. Snow

Received: 16 June 2021

Accepted: 23 July 2021

Published: 27 July 2021

Publisher's Note: MDPI stays neutral with regard to jurisdictional claims in published maps and institutional affiliations.

Copyright: (c) 2021 by the authors. Licensee MDPI, Basel, Switzerland. This article is an open access article distributed under the terms and conditions of the Creative Commons Attribution (CC BY) license (https:// creativecommons.org/licenses/by/ $4.0 /)$.

\begin{abstract}
Bacterial surface layers (S-layers) have been observed as the outermost cell envelope component in a wide range of bacteria and most archaea. S-layers are monomolecular lattices composed of a single protein or glycoprotein species and have either oblique, square or hexagonal lattice symmetry with unit cell dimensions ranging from 3 to $30 \mathrm{~nm}$. They are generally 5 to $10 \mathrm{~nm}$ thick (up to $70 \mathrm{~nm}$ in archaea) and represent highly porous protein lattices (30-70\% porosity) with pores of uniform size and morphology in the range of 2 to $8 \mathrm{~nm}$. Since S-layers can be considered as one of the simplest protein lattices found in nature and the constituent units are probably the most abundantly expressed proteins on earth, it seems justified to briefly review the different S-layer lattice types, the need for lattice imperfections and the discussion of S-layers from the perspective of an isoporous protein network in the ultrafiltration region. Finally, basic research on S-layers laid the foundation for applications in biotechnology, synthetic biology, and biomimetics.
\end{abstract}

Keywords: S-layer protein; surface crystal; self-assembly; lattice symmetry; lattice defects

\section{Introduction}

Patterns have inspired people for many years, especially when a certain order could be identified. It is not very difficult to find patterns at all length scales, from the particular constellations of stars in the universe to the fascinating array of (often colorful) amazing patterns or architectures in the living world. Examples include, among an almost unlimited number, the wings of butterflies or the complex frustules of diatoms. With the invention of the light microscope, then the electron microscope in the 1930s, and more recently scanning probe microscopes, our range of perception has been extended from the macro- to the micro- and nano cosmos. Symmetry operations, in particular, which are the characteristic of tiles, have always fascinated us with their redundancy and perfection. This goes back to patterns found in the Nazca culture in Peru, on Chinese porcelain, in the art of ancient Egypt and many others. With the discovery of inorganic crystal structures, such as the simple one of rock salt $(\mathrm{NaCl})$, their systematic investigation and the identification of symmetry elements, the foundation was laid for describing the ordered arrangement of atoms, ions or molecules in a coherent crystal system. According to this, the lattice is the repetitive distribution of points in space that describes the location of the unit cells of the crystal, and the combination with various symmetry elements (e.g., rotation axes, mirror or glide planes, screw axes, etc.) results in space groups that can be used to classify various arrangements of structures to fill space [1]. This classification scheme can also be applied to describe the symmetry properties of ordered arrangements of biomolecules in two and three dimensions. A well-known example is the study of biocrystals using X-ray crystallography. Monomolecular biological membranes have also been intensively studied in recent decades, as they represent the fundamental barriers in compartmentalization in the living world [2,3]. In this context, bacterial or archaeal surface layers (S-layers) [4,5], 
which consist of only a single protein or glycoprotein species with unit cell sizes in the 10 $\mathrm{nm}$ range, have attracted much attention, as their simple architecture and high relevanceas the outermost cell wall component-for bacterial and archaeal cells has already led to extensive knowledge of their structure, genetics, chemistry, morphogenesis and function. Most important, S-layers reveal a remarkable application potential as patterning elements in nanobiotechnology, biomimetics and synthetic biology [4,6,7], as well as to the development of biologically functionalized surfaces in the life sciences $[4,8]$. Since S-layer lattices can be considered as one of the simplest biological membranes that have developed during evolution, their lattice types, symmetry properties and unavoidable lattice defects on curved or lobed surfaces are themselves very interesting and have therefore been chosen as the focus of this review.

\section{Occurrence and Ultrastructure of S-Layers}

A large number of bacteria and most archaea are completely covered by a protein lattice called the Surface layer (S-layer) (Figure 1) [4,9-13]. Each bacterial or archaeal strain expresses its own specific S-layer proteins or glycoproteins. S-layer proteins have a molecular weight $\left(\mathrm{M}_{\mathrm{W}}\right)$ between 40 and $200 \mathrm{kDa}$, respectively, and are often glycosylated [14,15]. S-layers exhibit either oblique, square or hexagonal lattice symmetry, as shown in Figure 1 in examples of transmission electron microscopy (TEM) images. The unit cell dimensions of S-layers are in the range of 3 to $30 \mathrm{~nm}$, while the thickness is between 5 and $10 \mathrm{~nm}$ (up to $70 \mathrm{~nm}$ in archaea). Due to their crystalline character, S-layers are porous protein mesh works (30-70\% porosity) with pores of uniform size (2-8 nm) and morphology [16]. Although S-layer lattices usually occur as monomolecular surface crystals, there are exceptions where double layers are formed [17-19]. Moreover, it is also possible that more than one S-layer protein are expressed [19-21], or the S-layer is composed of two individual subunits [22].
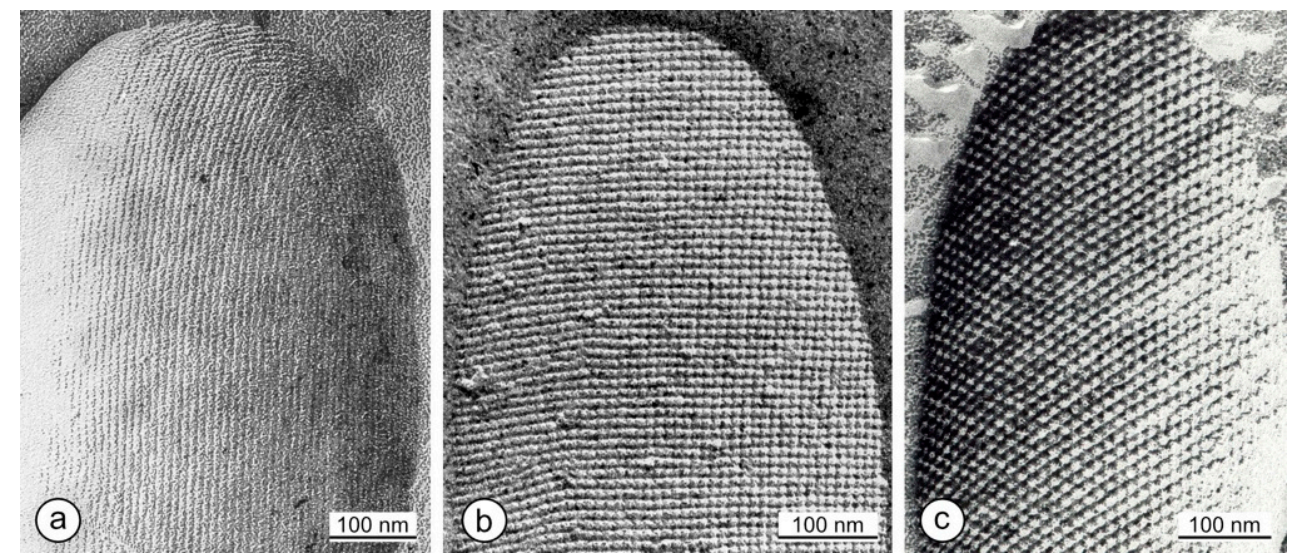

Figure 1. TEM images of freeze-etched metal shadowed preparations of (a) Geobacillus stearothermophilus NRS 2004-3a exhibiting an S-layer with oblique lattice symmetry (reproduced with permission from Reference [23]; published by Elsevier, 1986), (b) Desulfotomaculum nigrificans B200-71 exhibiting an S-layer with square lattice symmetry (reproduced with permission from Reference [24]; published by Springer I Nature, 1986), (c) Thermoanaerobacter Thermohydrosulfuricus L111-69 exhibiting an S-layer with hexagonal lattice symmetry (reproduced with permission from Reference [25]; published by Springer I Nature, 1989).

The widespread occurrence of S-layers raises the question of the selective advantage of S-layer-coated organisms in their natural and often highly competitive habitats. After all, to completely cover a rod-shaped bacterial cell, about 500,000 S-layer monomers are required, which, assuming a generation time of $20 \mathrm{~min}$, requires the synthesis and translocation of more than 400 copies of a single polypeptide chain per second [26]. In this context, it should be noted that $\mathrm{S}$-layer proteins are among the most frequently expressed proteins on earth [4]. 
In Gram-positive bacteria (e.g., Bacillaceae), studies of different S-layers showed the existence of specific binding domains at the N-terminal part of the proteins for heteropolysaccharides (secondary cell wall polymers (SCWPs)), which themselves are covalently bound to the peptidoglycan matrix of the cell wall $[27,28]$.

In Bacillaceae, S-layers are highly anisotropic structures in terms of their topographical and physicochemical surface properties. In most cases, the topography of the inner S-layer surface is strongly corrugated, while the outer one is rather smooth (Figure 2a). The surface charge of the inner S-layer surface is either net negative when free carboxyl groups or net positive when free amino groups dominate. The outer surface is usually net charge neutral and shows remarkable antifouling properties (Figure 2b) [16,29-31].

(a)

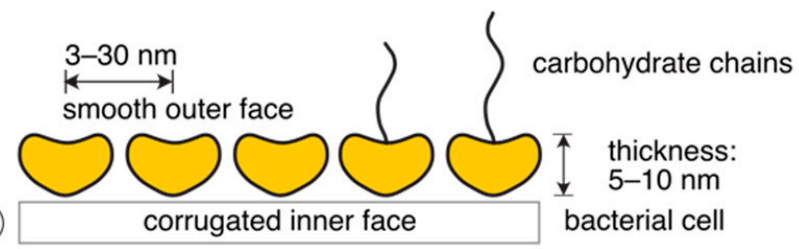

\section{(b)}

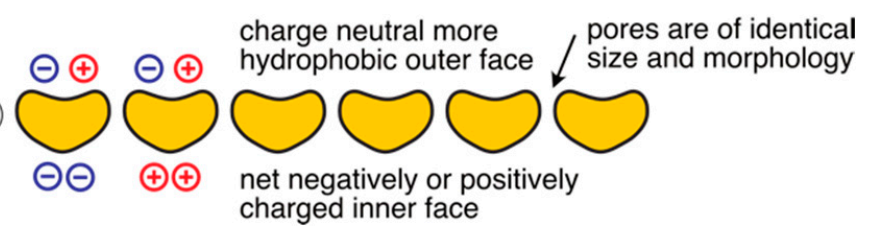

Figure 2. Schematic drawings of the (a) topographical and (b) physicochemical surface properties of S-layers from Bacillaceae.

\section{Reassembly of S-Layer Proteins}

One of the key properties of isolated and purified S-layer proteins from bacteria is their natural ability to reassemble after isolation and purification on the cell surface of their origin (homologous reattachment) [32] or on cell surfaces of taxonomically closely related strains (heterologous reattachment) [33]. Further, S-layer subunits can assemble into extended two-dimensional crystalline arrays in solution, on solid supports, at the air-water interface, on lipid layers, liposomes or emulsomes (Figure 3) (for review see References [4,34,35]). The reassembled S-layer protein layer shows the same lattice parameters as on the bacterial cell. For a detailed description of the isolation, purification and/or recombinant production of S-layer proteins, the reader is referred to several reviews $[4,34,36,37]$.

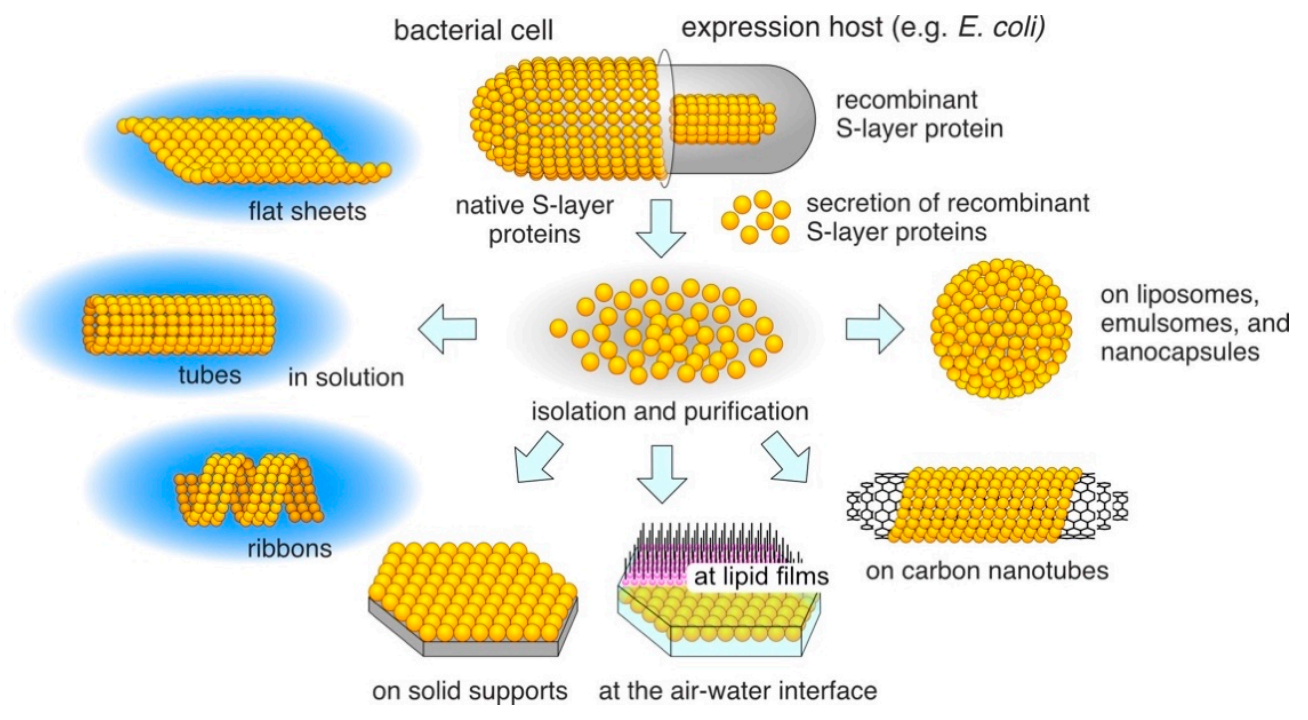

Figure 3. Schematic drawing of the different reassembly routes of S-layer proteins. 


\section{Reassembly in Solution}

S-layers provide interesting models for studying the dynamic process involved in the self-assembly of a simple biological supramolecular structure on growing and dividing cells. For a better understanding of the formation of this entropy-driven low energy structure, numerous studies on the self-assembly of isolated S-layer subunits were performed $[4,5,11-13,36,38]$.

Self-assembly products of S-layer proteins are formed in solution during the dialysis of the disrupting agent used for their isolation against a buffer with specific ionic content, strength, and $\mathrm{pH}$ [39]. Concentration-dependent light scattering revealed multiphase kinetics with a fast initial phase in which oligomeric precursors are formed, which then serve as nucleation sites for crystal growth in a second, slower step [40].

Depending on the morphology and binding properties of the S-layer proteins, flat singleor double-layered sheets, ribbon-like morphologies or open-ended tubes are formed [23,39,41]. In one particular case, where the S-layer exhibited hexagonal lattice symmetry, closed vesicles were also formed [32]. In some cases, it was possible to obtain different assembly products by simply changing the assembly conditions such as $\mathrm{pH}$, temperature, ionic strength, and the presence or absence of divalent cations [39]. For example, the S-layer protein SgsE from Geobacillus stearothermophilus NRS 2004/3a assembled in this manner to form both flat and cylindrical monolayer and double layer self-assembly products with different diameters [23]. While sheets and cylinders with diameters between $\sim 220 \mathrm{~nm}$ and $\sim 1 \mu \mathrm{m}$ were always double layers in back-to-back orientation, small cylinders with diameters between $\sim 70$ and $\sim 100 \mathrm{~nm}$ consisted of monolayers. With regard to their rotational superposition, the double layers could be divided into five different superposition types.

\section{Reassembly at the Liquid-Solid Interface}

The reassembly of S-layer proteins on solid surfaces, such as mica or silicon, or solid supported self-assembled monolayers is a good example of the non-classical multi-stage reassembly pathway of biomolecules on surfaces [42-45]. In this model, it is assumed that (partially) unfolded monomers first attach to the surface, form amorphous and then microcrystalline clusters. The final crystalline domains are obtained in an associated refolding step. The importance of amorphous precursors and folding transitions was first investigated with SbpA, the S-layer protein from Lysinibacillus sphaericus ATCC4525, by high-resolution atomic force microscopy (AFM) [42]. Furthermore, SbpA was used to show that kinetic trapping leads to more than one pathway to the final reassembled mosaic of crystalline domains [43] following distinct dynamics [45]. Calcium ions play an important role in the reassembly of most S-layer proteins, including SbpA [41-48]. In the growing crystal lattice of SbpA with its square (p4) lattice symmetry, four monomers must first find their correct position and orientation step-by-step before the assembly of the next unit cell is started [49]. In this way, the non-classical reassembly pathway can also explain the self-purification of growing crystalline arrays [50].

An atomic force microscopy (AFM) and a TEM image of crystalline domains of the reassembled S-layer protein SbpA of L. sphaericus CCM2177 (equivalent to L. sphaericus ATCC4525 [12]) and the S-layer protein of B. coagulans E38-66, respectively, are shown in Figure 4 . 

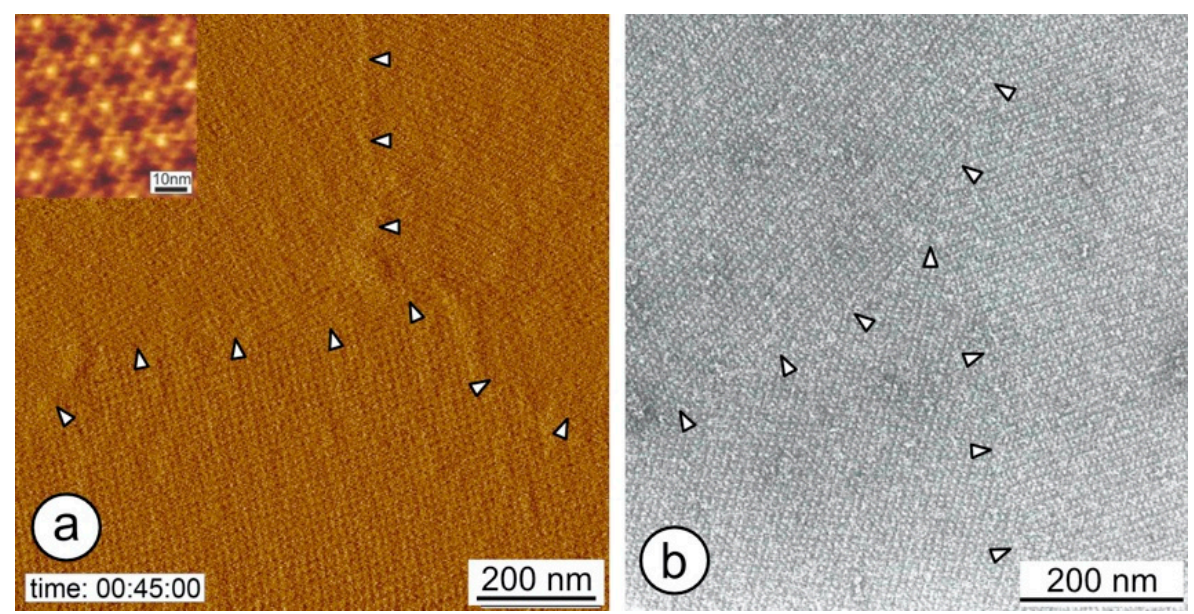

Figure 4. (a) AFM image of a mosaic of self-assembled S-layer domains of SbpA on a silicon surface $45 \mathrm{~min}$ after injection of the protein into the liquid cell. The inset shows a high-resolution AFM image of SbpA. The square (p4) lattice symmetry is clearly visible (reproduced with permission from Reference [51]; published by Wiley and Sons, 2003). (b) TEM micrograph of a negatively stained preparation of crystalline domains of the oblique S-layer lattice of B. coagulans E38-66 reassembled on a poly-L-lysine coated EM-grid (reproduced with permission from Reference [52]; published by the American Society for Microbiology, 1989). The grain boundaries are marked by arrows in both panels.

Moreover, since S-layer proteins have a high proportion of non-polar amino acids, hydrophobic interactions are probably involved in the assembly process. With regard to the intramolecular forces, it should be noted that free carboxylic acid groups and amino groups are in close proximity on the S-layer surface and will thus contribute to the cohesion of the protein through electrostatic interactions. In archaea, the S-layer proteins are strongly linked [5], making the isolation and purification of S-layer proteins difficult, whereas in eubacteria, the intermolecular forces between the S-layer proteins and the bacterial cell wall are determined by non-covalent interactions, such as various combinations of weak bonds (hydrophobic bonds, ionic bonds, direct interaction of polar groups, and hydrogen bonds) [53]. In fact, for enabling the continuous rearrangement of newly incorporated S-layer subunits into a coherent lattice on the growing cell, the bonds holding the S-layer proteins together must be stronger than those to the underlying cell envelope layer [33]. This conclusion was supported by studies on the reconstitution of isolated S-layer proteins on the cell surfaces of various Bacillaceae from which they had been removed (homologous reattachment) or on those of other organisms (heterologous reattachment) [32,33]. In contrast to the large crystalline arrays on intact cells, the crystalline patches were much smaller. It was also shown that the S-layer proteins of one organism could also reattach to the cell wall of the other with their original lattice symmetry (square vs. hexagonal). Furthermore, if a mixture of both S-layer protein types was provided, small patches of both lattice types were formed in a kind of crazy paving (Figure 5). A further interesting observation was made when the $\mathrm{pH}$ was lowered below 3 . The square and hexagonal patterns were no longer detectable in freeze-etched or negatively stained preparations but reappeared when the $\mathrm{pH}$ was raised to 7 again. These observations indicated that the S-layer proteins had not been removed but were denatured to such an extent that a layer with a random granular structure was formed. These observations clearly showed for the first time that the information for lattice formation and orientation lies in the proteins themselves and is not determined by the support [32,33]. As already described for the nonclassical pathway, the S-layer proteins are free to move and reorient until they find their correct position in the growing crystalline domain - a need for the assembly of a coherent extended layer [49]. 


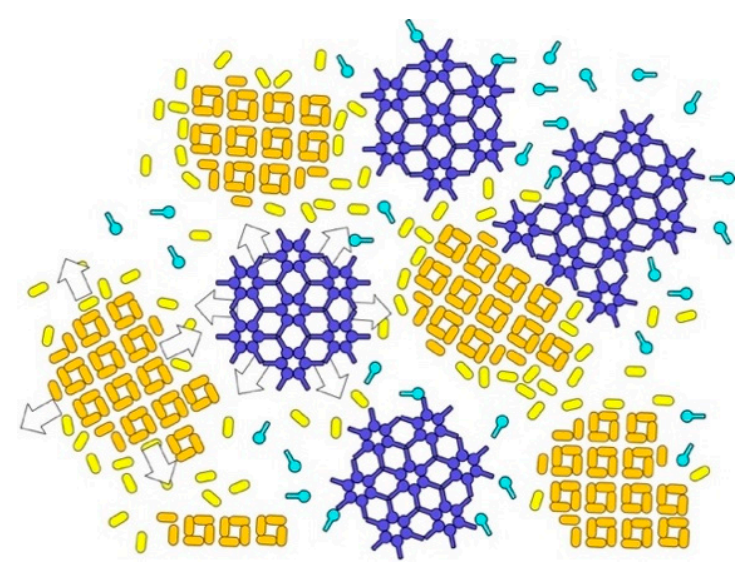

Figure 5. Schematic drawing of the heterologous reassembly of two different S-layer proteins with square and hexagonal lattice symmetry, respectively. According to the non-classical, multi-stage reassembly process, proteins in the crystalline domains have undergone a transformation into compact monomers (orange and dark blue) compared to the extended proteins still in solution or amorphous clusters (yellow and light blue).

A wide variety of supports, differing in their surface properties, have already been investigated to meet new (nano)technological requirements [34]. Silicon, glass, metal surfaces, polymers, and more recently graphene [54] have been exploited for applications in materials and life sciences $[6,55]$. In most cases, the surface must be made hydrophilic or hydrophobic by plasma treatment prior to application. For example, in situ AFM showed that the S-layer protein SbpA reassembled much faster on hydrophobic compared to hydrophilic surfaces (30 min vs. $60 \mathrm{~min}$ for complete coverage) [51,56]. However, the size of crystalline domains was much larger on hydrophilic surfaces with mean diameters of 2-10 $\mu \mathrm{m}$ compared to $200 \mathrm{~nm}$ on hydrophobic surfaces.

Most recently, the anisotropy between the inner and outer SbpA S-layer surface was used to develop a novel tuneable method for cellular micropatterning [31]. By simply altering the recrystallization protocol from basic $(\mathrm{pH} 9)$ to acidic $(\mathrm{pH} 4)$ conditions, the SbpA S-layer orientation was adjusted to effectively prevent protein adsorption and cell adhesion (smooth outer cytophobic side exposed), or, alternatively, to promote cell attachment and spreading (rough inner cytophilic side exposed) (pI of SbpA is 4.6).

\section{Reassembly at the Air-Water Interface, at Lipid, and Polyelectrolyte Layers}

Reassembly of S-layer proteins at the air-water $(\mathrm{a} / \mathrm{w})$ interface from the subphase [46], on planar lipid layers and self-assembled monolayers [46,57,58], on liposomes of various sizes [59], emulsomes [35,60,61], and on polyelectrolyte layers [62], to name but a few, follows the same mechanisms as explained for the reassembly on solid supports before (Figures 3 and 4). Nevertheless, the hydrophobicity/hydrophilicity of the surface [57], the net surface charge of the lipid head groups, or the exposed polyelectrolyte layer determines whether the S-layer proteins are bound with their inner or outer surface to the interface (for a review, see [63]).

\section{Two-Dimensional Crystal Terminology}

S-layer lattices can also be formally described as two-dimensional crystals. On the basis of the various symmetry elements, they can be divided into space groups [1]. It is known that there are 230 three-dimensional space groups, while there are only 17 twodimensional plane groups. Since these plane groups only provide information in a single plane, they are often called one-sided plane groups. However, a real planar crystal usually has two distinguishable faces, which introduces a third direction and leads in this additional information to a total of 80 two-sided plane groups, or two-dimensional space groups (2D-space groups) [64,65]. A list of the 80 two-sided plane groups, divided with respect 
to their lattice types, is presented as Table A1 in the Appendix A. Nevertheless, real biological molecules, such as S-layer proteins, can never be related to each other by mirror or glide planes or inversion centers because they have a certain handedness-they are chiral. From the 80 two-sided plane groups, only 17 groups contain no mirror or glide planes or inversion centers and thus fulfil this requirement. These 17 selected groups are shown in Table 1. For these 17 two-sided plane groups, there is a one-to-one relationship (projection symmetry) to the 17 one-sided plane groups. Of course, the relationship applies in one direction only.

Table 1. The 17 two-sided plane groups allowed for biological molecules. These contain no mirror or glide planes or inversion centers [1]. The nomenclature of Holser is used [64]. The symbols are written in the following sequence: (1) Cell type indicated by a small letter, $\mathrm{p}$ (primitive) or c (centered), (2) axis perpendicular to the plane, arbitrarily chosen as the $z$-axis, (3) symmetry in the plane, along an axis designated $x$, and (4) symmetry in another direction in the plane.

\begin{tabular}{|c|c|c|c|c|}
\hline No. & $\begin{array}{c}\text { Two-Sided } \\
\text { Plane Group } \\
\text { (2D-Space Group) }\end{array}$ & $\begin{array}{l}\text { One-Sided Plane Group } \\
\text { (2D-Plane Group) } \\
\text { (Projection Symmetry) }\end{array}$ & Lattice Type & $\begin{array}{l}\text { S-Layer Lattice } \\
\text { Symmetry }\end{array}$ \\
\hline 1 & $\mathrm{p} 1$ & $\mathrm{p} 1$ & \multirow[b]{2}{*}{ oblique } & p1 \\
\hline 2 & p21 & p2 & & p2 \\
\hline 3 & $\mathrm{p} 12$ & $\mathrm{pm}$ & \multirow{7}{*}{ rectangular } & - \\
\hline 4 & p $12_{1}$ & $\mathrm{pg}$ & & - \\
\hline 5 & c12 & $\mathrm{cm}$ & & - \\
\hline 6 & p222 & $\mathrm{pmm}$ & & - \\
\hline 7 & p222 & pmg & & - \\
\hline 8 & $\mathrm{p} 22_{1} 2_{1}$ & pgg & & - \\
\hline 9 & c222 & $\mathrm{cmm}$ & & - \\
\hline 10 & $\mathrm{p} 4$ & $\mathrm{p} 4$ & \multirow{3}{*}{ square } & $\mathrm{p} 4$ \\
\hline 11 & p422 & $\mathrm{p} 4 \mathrm{~m}$ & & 1 \\
\hline 12 & $\mathrm{p} 42_{1} 2$ & $\mathrm{p} 4 \mathrm{~g}$ & & - \\
\hline 13 & p3 & p3 & \multirow{5}{*}{ hexagonal } & p3 \\
\hline 14 & p312 & p3m1 & & P \\
\hline 15 & p321 & p31m & & - \\
\hline 16 & p6 & p6 & & p6 \\
\hline 17 & p622 & p6m & & - \\
\hline
\end{tabular}

Finally, S-layer proteins in an S-layer lattice can never be related to each other by two-fold axes in the layer plane, because in this case, one protein would lie next to another in reversed orientation (outer versus inner side). This is not possible, and thus, S-layer lattices have either only p1, p2, p4, p3 or p6 lattice symmetry (Table 1 and Figure 6). In fact, the remaining two-sided plane groups have never been observed in S-layers $[12,66,67]$.

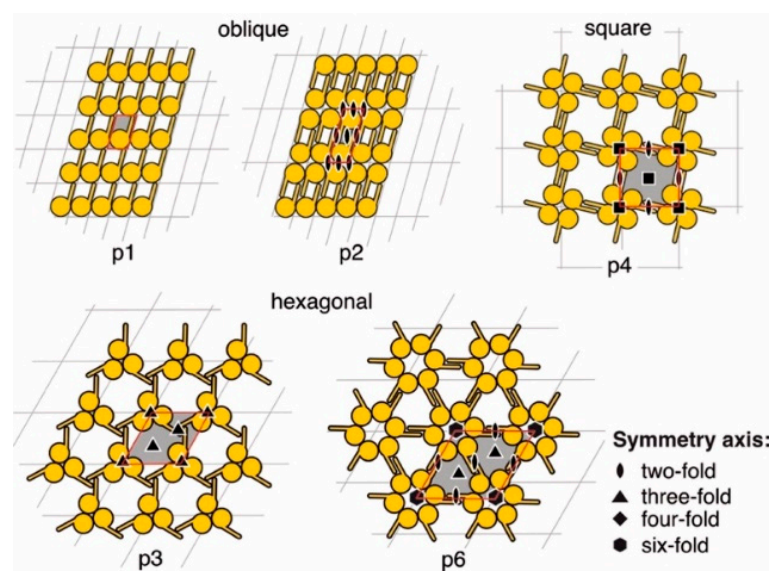

Figure 6. Schematic drawing of the five different S-layer lattice types with their symmetry axes. Unit cells are marked in grey and outlined in red (reproduced with permission from Reference [4]; published by Oxford University Press, 2014). 
Figure 7 shows examples from TEM studies of negatively stained preparations. The signal-to-noise ratio (SNR) was improved by digital image processing. A digital filter mask was applied to the Fourier spectrum to remove noise [68].
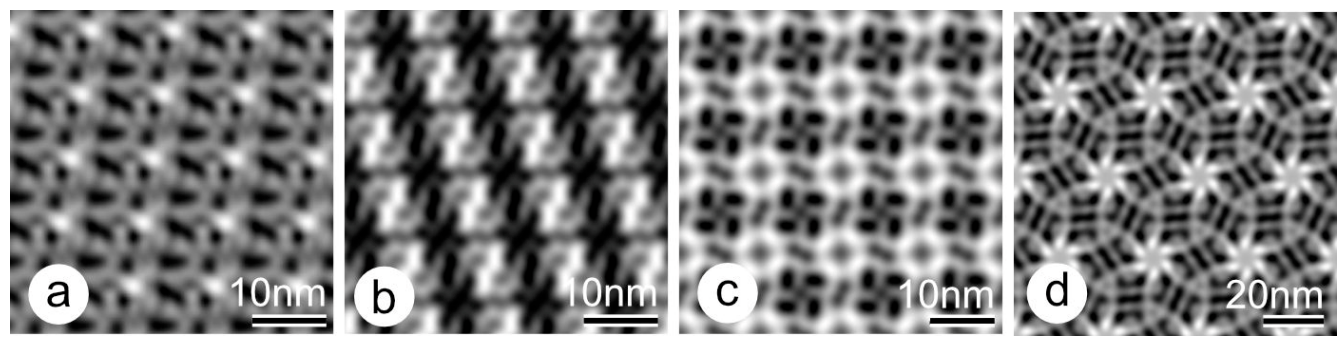

Figure 7. TEM images of negatively stained preparations of S-layer lattices with different lattice symmetries. (a) SbsB from G. stearothermophilus PV72/p2 with oblique (p1) lattice symmetry, (b) SgsE from G. stearothermophilus NRS 2004/3a with oblique (p2) lattice symmetry (reproduced with permission from Reference [23]; published by Elsevier, 1986), (c) SbpA from L. sphaericus CCM2177 with square (p4) lattice symmetry (reproduced with permission from Reference [46]; published by Elsevier, 1994), and (d) the S-layer protein of the archaeon Th. tenax with hexagonal (p6) lattice symmetry (reproduced with permission from Reference [69]; published by the American Society for Microbiology, 1986). Protein is bright, while the staining in the pores and wells is dark.

In addition to this strictly mathematical concept of defining crystal structures, Saxton and Baumeister proposed a classification scheme as early as 25 years ago that encompasses all the different ways in which an asymmetric unit consisting of a massive domain (M) and a lighter connecting arm (C) can be arranged to construct a coherent network of proteins, especially S-layer proteins. They introduced the term $\mathrm{M}_{n} \mathrm{C}_{\mathrm{m}}$, in which the heavier domain $\mathrm{M}$ is arranged around an $\mathrm{n}$-fold axis and the connecting arms around an $\mathrm{m}$-fold axis [70]. Nevertheless, it must also be mentioned that real S-layer proteins may differ substantially from these simple forms and have additional connecting arms, but these examples would require more elaborate schemes [70].

An overview of a wide range of the three-dimensional models of S-layer lattices obtained by TEM may be found in References [66,67,71], and more recently in [12].

Although enormous efforts were made to elucidate the atomic structure of S-layer proteins by X-ray crystallography, it turned out that originally only truncated forms were accessible, as only these formed three-dimensional crystals [72-74]. The first full-length structure of an S-layer protein, namely the S-layer protein SbsB of Geobacillus stearothermophilus PV72/p2 [21], was obtained in 2012 by making use of the nanobody-aided crystallization approach [47]. Although several models of the three-dimensional structure of S-layer proteins have been published down to a resolution of 2.5 Angstrom [75-78], it appears that cryo-transmission electron tomography and sub-tomogram averaging or combinations of X-ray scattering and cryo-electron microscopy are now the methods of choice to obtain near atomic resolution [22,49,79-81].

\section{Lattice Imperfections}

Since the morphological units in S-layer lattices are generally not arranged in the theoretically regular position that would be expected in a perfect 2D crystal, various image processing methods have been developed to improve the signal-to-noise ratio (SNR) in TEM images [82,83]. First attempts to correct for spatial distortions prior to averaging in images of negatively stained S-layer preparations showed that S-layers are highly porous structures consisting of subunits connected by fine arms [82]. Later, freeze-etching preparations of intact cells frozen at a rate of several thousand Kelvin per second confirmed the significant irregularities in the S-layer lattices $[10,11,39]$. Therefore, it is tempting to speculate that in native S-layers the constituent subunits are subject to thermal vibrations. A phenomenon that could be essential to loosen the bonds between the subunits as the lattice grows and adopt a low free energy arrangement. 
Moreover, it is a fact that even thin surface crystals, such as S-layers, cannot follow the curved surfaces of bacterial cell poles or of lobed cells without the introduction of lattice defects, such as wedge disclinations and edge dislocations [84]. This is because the S-layer has a double curvature in many cases. Removing a wedge along the main directions (primitive base vectors) in a two-dimensional lattice results in a positive wedge disclination, while its insertion results in a negative wedge disclination [85]. For example, removing a $60^{\circ}$ wedge in a hexagonal arrangement results in a $+60^{\circ}$ wedge-disclination, which is visible as a pentagon, while a $-60^{\circ}$ wedge-disclination is a heptagon. The introduced strain is absorbed by the two-dimensional lattice by buckling. While positive wedge disclinations form circular cones, negative ones lead to saddle-like structures [84]. While the presence of disclinations is a geometrical necessity, dislocations are the natural growth points in a surface crystal [86]. It can be proved that any surface that can be topologically deformed into a sphere, such as a bacterial cell, must have disclinations with a total rotation of $4 \pi\left(=720^{\circ}\right)$ according to the fundamental theorem of geometry proved by Leonhard Euler [87]. The total rotation of $720^{\circ}$ can be distributed in many ways but the $12 \times 60^{\circ}$, as suggested by Casper and Klug [88] for the construction of virus shells, are the most likely ones. This theoretically expected number of $60^{\circ}$ wedge disclinations was detected in the shape determining hexagonal S-layers of the rod-shaped archaea Thermoproteus tenax and Thermoproteus neutrophilus [69]. While no dislocations could be observed on the cylindrical part, six wedge disclinations could be visualized on each hemispherical cap (Figure 8a). This was particularly interesting as dislocations are generated (or annihilated) when wedge disclinations are displaced-a natural process in a growing bacterial or archaeal cell [89]. Edge dislocations are the natural growth points (vacancies) in a surface crystal into which new protomers can be inserted-a process called "intussusception" [86]. As a result, the dislocation climbs one lattice spacing to the new position-a process that can be repeated indefinitely unless prevented by the interaction with another dislocation or disclination. Just for the sake of completeness, edge dislocations may also move perpendicular to the climb direction, but then no new protomers are incorporated. The fact that these imperfections are crucial for the cell growth was further investigated using the hexagonal S-layer of Methanocorpusculum sinense (Figure 8b-d) [84]. The S-layer of this highly lobed organism shows a porous but strongly interconnected network. In TEM images of freeze-etched preparations of intact cells, numerous pentagons $\left(+60^{\circ}\right.$ wedge disclinations) and heptagons $\left(-60^{\circ}\right.$ wedge disclinations) could be identified in the hexagonal array. Most of them were found in close proximity and formed so called complementary pairs ( $\mathrm{cp}$ ) of pentagons and heptagons. They could be identified as endpoints of edge dislocations where new morphological units can be inserted into the growing S-layer lattice. The intussusceptive growth of S-layers by climbing dislocations has several interesting properties. Lattice growth occurs at well-defined centers, the number of which may vary depending on the internal stress exerted by the growing cell. The process has vectorial character, the rigidity of the S-layer lattice, which also determines the cell shape, is maintained, and the overall shape of the archaeal cell has not changed significantly. Furthermore, complementary pairs were found to be also the initiation points in the cell division process. The fissioning of the cell can be represented by the generation and subsequent movement of a $-2 \pi$ wedge disclination [87]. The disclination point is at the end of the resulting fission, while the "corners" created in this way are positive wedge disclinations with rotations $2 \psi$ and $2(\pi-\psi)$, respectively. $\psi$ is the angle at which the path of the disclination point crosses the edge. This mechanism provides an organized way for cells coated with an S-layer to divide without spilling their contents. It has to be stressed that in such hyperbolic surfaces, as the $-2 \pi$ wedge disclination, the strain is relaxed by bending and, in this way, 3D symmetries are formed. More examples exist in nature, such as the minimal Scherk surfaces of twist grain boundaries in 3D-lamellar Turing structures [90], or the asymmetric ion-channel model of the peptide antibiotic alamethicin [91]. Analysis of the number and distribution of lattice defects confirmed that 
the S-layer recrystallizes continuously during cell growth and maintains an equilibrium of the lowest free energy [84].
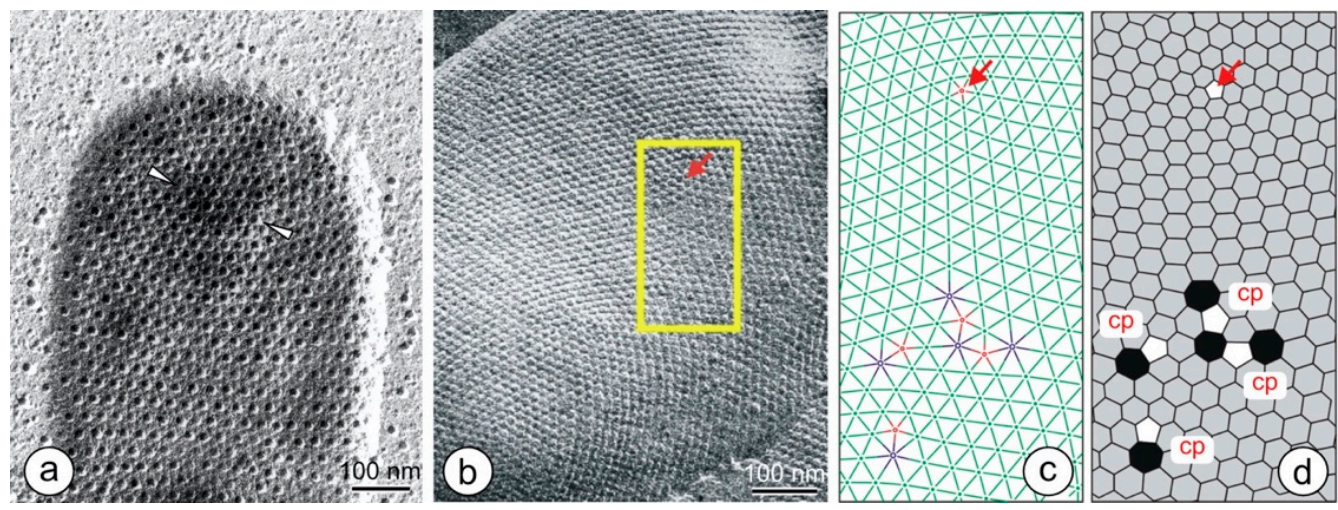

Figure 8. TEM images of freeze-etched and metal shadowed preparations of (a) Th. tenax and (b) M. sinense. In (a), the hexagonal S-layer lattice was highlighted by labeling each morphological unit with a polycationic ferritin (PCF) molecule. Arrows indicate local $+60^{\circ}$ wedge disclination in the hexagonal S-layer lattice (reproduced with permission from Reference [69]; published by the American Society for Microbiology, 1986). (c) Relative to the marked area in (b), hexagonal lattice positions are shown in green, five-fold positions $\left(+60^{\circ}\right.$ wedge disclinations) in red, and the seven-fold positions $\left(-60^{\circ}\right.$ wedge disclinations) in blue. In (d), hexagons, pentagons, and heptagons are shown as Voronoi cells. Pentagon-heptagon pairs are called complementary pairs and are considered initiation points for the incorporation of new S-layer proteins into the S-layer lattice of the growing archaeal cell $((\mathbf{b}, \mathbf{c})$ reproduced with permission from Reference [84]; published by the American Society for Microbiology, 1991).

Screw dislocations were obtained when stirring the S-layer protein solution during dialysis (Figure 9a). It is therefore likely that a point defect impedes isotropic crystal growth, and thus, the S-layer lattice eventually grows along a screw around the defect [34].
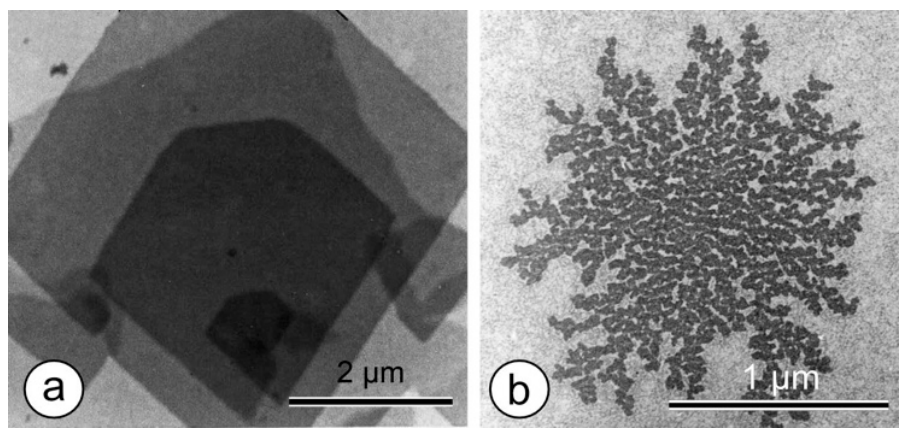

Figure 9. (a) Screw dislocations form in solution when the SgsE-S layer protein solution is stirred during the reassembly process. (b) Fractal-like structures are formed by SbpA when the calcium ion concentration is below a critical limit.

The importance of calcium concentration (in the subphase) for the reassembly of SbpA was first demonstrated by studying anisotropic crystal growth at the air-water interface [92]. Depending on the calcium concentration, a wide spectrum of crystal morphologies was found, ranging from delicate fractal-like structures to micrometre-sized monocrystalline patches (Figure 9b). Nevertheless, all morphological units in the cluster had the same orientation and were not displaced from each other. Although the shape of the clusters was irregular, the S-layer branches showed undisturbed square $(\mathrm{p} 4)$ lattice symmetry. When the recrystallization time was extended from 12 to $48 \mathrm{~h}$, the holes and gaps were filled.

\section{Changes in the Ultrastructure of the Same S-Layer Protein}

In the course of studying structure-function relationships of different amino acid (aa) segments in the S-layer protein SbpA from L. sphaericus CCM2177, the unexpected 
observation was made that the deletion of a certain number of amino acids has a dramatic effect on the lattice structure [93]. The full length of $\mathrm{SbpA}_{31-1268}$ comprises 1238 aa. The C-terminally truncated form $\mathrm{rSbpA}_{31-1068}$, which is mostly used as the self-assembling building block in the construction of various S-layer fusion proteins, is 1038 aa long [4]. S-layer fusion proteins assemble into two-dimensional arrays and offer the introduced functional domain to bind molecules [8]. When screening different truncated forms of SbpA, it was found that the original S-layer lattice, which has square lattice symmetry, changed to a lattice with oblique lattice symmetry when 350 C-terminal aa had been deleted (Figure 10). Moreover, the ultrastructure of this newly formed S-layer lattice was almost identical to that of SbsB, the S-layer protein of G. stearothermophilus PV72/p2 [94]—as determined in TEM images of negatively stained preparations with a resolution of $\sim 2 \mathrm{~nm}$. It is interesting to note that the full-length S-layer protein SbsB comprises amino acids 32 to 920, whereas the newly formed $\mathrm{rSbpA}_{31-918}$ is only one aa longer. While both S-layer proteins had three SLH motifs with high identity at the N-terminal part, no sequence identities were found for the middle and C-terminal parts. Further truncation of $\mathrm{rSbpA}_{31-918}$ resulted in a complete loss of the self-assembly properties of the S-layer protein (Figure 10).

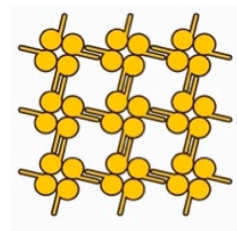

(a) $\mathrm{rSbpA}_{31-1268}$

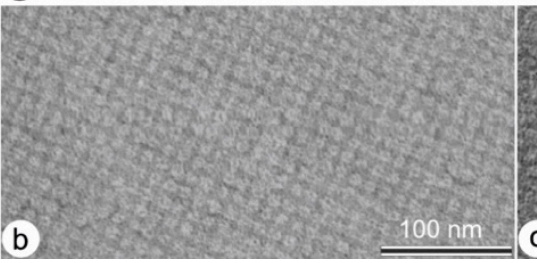

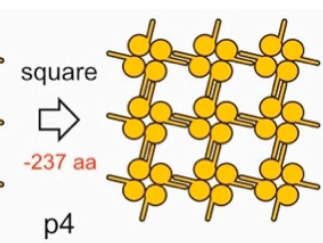

$\mathrm{rSbpA}_{31-1031}$

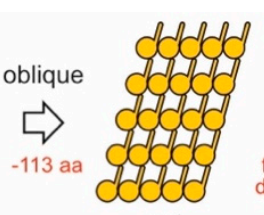

p1

$\mathrm{rSbpA}_{31-918}$

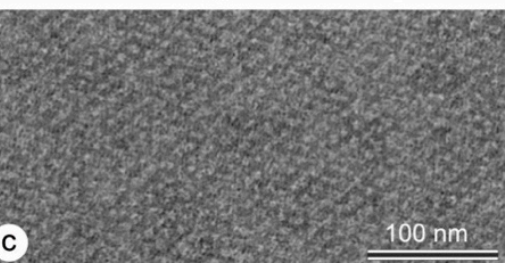

Figure 10. (a) Schematic drawing of the transformation of the SbpA S-layer lattice symmetry from square to oblique, and finally, the complete loss of crystallinity; (b) TEM image of the rSbpA $31-1268$ lattice showing square (p4), and (c) of the $\mathrm{rSbpA}_{31-918}$ lattice exhibiting oblique (p1) lattice symmetry [93] (reproduced with permission from Reference [36]; published by MDPI AG, 2013).

In this context, it is interesting that the ultrastructure of SbsB was also found as a variant of the S-layer of B. stearothermophilus NRS2004/3a under oxidative stress [20]. After removal of the oxygen limitation during the fermentation process, two different variants, one with oblique S-layer lattice symmetry (variant 3a/V1) and one with square S-layer lattice symmetry (variant $3 a / V 2$ ) could be identified on the bacterial cells. Variant $3 \mathrm{a} / \mathrm{V} 1$ showed identical lattice parameters and-at a resolution of $\sim 2 \mathrm{~nm}$-identical protein mass distribution to SbsB. Although the protein mass distributions were quite different in the S-layer lattices from the wild-type and the two variant strains (V1 and V2), neither the amino acid composition nor the pore size had changed significantly. Peptide mapping and N-terminal sequencing showed that the three S-layer proteins were encoded by different genes [20]. In summary, it must be stated that although the described S-layer proteins look very similar to SbsB in their ultrastructure, they differ significantly in their biochemical properties.

\section{Pores in the S-Layer Structure}

The first technological applications of S-layers made use of the geometrically welldefined pores defined by the S-layer protein lattice. Since an S-layer lattice can be simply described by the periodic arrangement of protein domains connected by arms, it is obvious that only a few different pore sizes are possible in the protein network. In order to determine the pore sizes in S-layer lattices of different Bacillaceae, permeability studies 
with sugars, proteins, and dextrans of increasing molecular weights were performed [95]. It was clearly demonstrated that the S-layer lattices are isoporous molecular sieves that show sharp exclusion limits between molecular weights of 30 and $45 \mathrm{kDa}$. In addition, functional groups located on the surface or in the pores can be made accessible by chemical modifications $[53,95-97]$ that make them more hydrophobic, for example, or serve to bind functional molecules, such as small nucleophiles that reduce the pore diameter as in an iris diaphragm [98]. For technical applications, such as the development of S-layer ultrafiltration membranes (SUMs), the sc. effective pore size is therefore important [16,99]. SUMs are sandwich-like architectures consisting of a supporting highly porous microfiltration or radiation track membrane to which S-layer-carrying cell wall fragments or self-assembled S-layer sheets were deposited. Like roofing, the S-layer "tiles" form a closed layer and, after cross-linking, result in a robust ultrafiltration layer with very steep rejection curves [99]. The porosity was found to be between $30 \%$ and $70 \%$. Furthermore, it should be mentioned that the antifouling properties of S-layers were another advantage of SUMs [16].

\section{Summary}

The natural ability of S-layer proteins to assemble into extended crystalline arrays, especially on solid supports, is fascinating, and the sheer simplicity of the protein network acts as an inspiration for the development of a biomolecular construction kit. S-layer proteins have already shown a broad application potential in the material and life sciences; the reader is referred to several reviews $[4,6,8,16,100-104]$. In particular, the design and expression of S-layer fusion proteins in which a specific biologically or biomedically relevant functionality, such as the IgG binding domain [105], is exposed, enabled the development of a completely new class of affinity matrices and biosensors [106]. A complete list of S-layer fusion proteins and their fields of application can be found in Reference [4]. Moreover, functionalized S-layers can be stabilized by inter- and intramolecular cross linking without loss of function of the fused moiety $[4,6,16]$. In addition, S-layer lattices have remarkable antifouling properties [16], which have already been used for the coating of channel surfaces in microfluidic devices [31,107].

Nevertheless, S-layer lattices are surface crystals and based on this, their symmetry properties can be studied and described with the tools of crystallography [1]. This is especially true for a wide range of two-dimensional biological crystals, including S-layers, when studied with low-dose and cryo-electron microscopy, where the signal-to-noise ratio is extremely low. Careful examination of the reciprocal lattice in Fourier space then allows accurate determination of the lattice parameters (basis vectors and basis angles), lattice symmetry and resolution of image details of the samples [68]. Cryo-electron tomography and sub-tomogram averaging have opened the door to a new area of biological ultrastructural research, ultimately leading to new insights into the molecular structure of S-layer proteins at atomic resolution $[77,79,80,108]$.

Author Contributions: Conceptualization, D.P., A.B. and U.B.S.; resources, D.P.; writing-original draft preparation, D.P.; writing-review and editing, D.P., A.B. and U.B.S.; visualization, D.P. and U.B.S.; supervision, D.P.; project administration, D.P.; funding acquisition, D.P. All authors have read and agreed to the published version of the manuscript.

Funding: This research was funded by the Austrian Science Fund (FWF): (project P 31927-N28) (to D.P.).

Data Availability Statement: Not applicable.

Acknowledgments: The funding of the Austrian Science Fund (FWF), project P 31927-N28 (to D.P.) and financial support provided from Avalon GloboCare Corp. is gratefully acknowledged.

Conflicts of Interest: The authors declare no conflict of interest. 


\section{Appendix A}

The 80 Two-Sided Plane Groups (2D-Space Groups)

The 17 two-sided plane groups allowed for biological molecules are marked in red. These contain no mirror or glide planes or inversion centers.

Nomenclature by Holser [64]: The symbols are written in the following sequence:

1. Lattice type indicated by a small letter, $\mathrm{p}$ (primitive) or c (centered),

2. Symmetry in a direction normal to the plane, arbitrarily taken as the $z$-axis,

3. Symmetry in the plane, along an axis designated $x$, and

4. Symmetry in another direction in the plane.

The notation is consistent with the Hermann-Maugin form of the International Tables for Crystallography [1].

Table A1. The 80 two-sided plane groups (2D-space groups) and their lattice types.

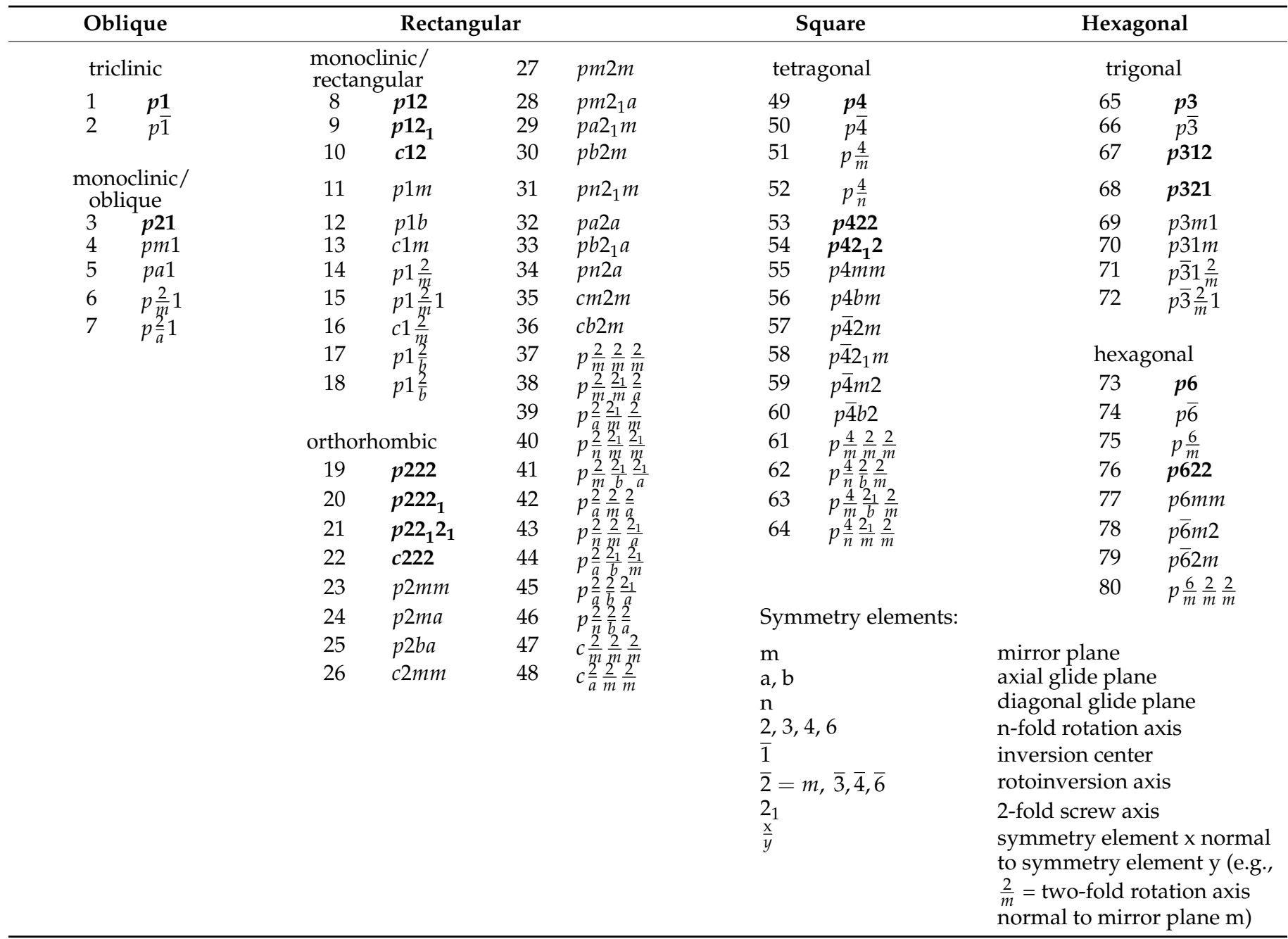

\section{References}

1. Hahn, T. (Ed.) International Tables for Crystallography: Volume A: Space-Group Symmetry, 5th ed.; The International Union of Crystallography; John Wiley\&Sons, Ltd.: Chichester, UK, 2006.

2. Mann, S. The Origins of Life: Old Problems, New Chemistries. Angew. Chem. Int. Ed. 2013, 52, 155-162. [CrossRef] [PubMed]

3. Mann, S. Life as a nanoscale phenomenon. Angew. Chem. Int. Ed. 2008, 47, 5306-5320. [CrossRef]

4. Sleytr, U.B.; Schuster, B.; Egelseer, E.M.; Pum, D. S-layers: Principles and applications. FEMS Microbiol. Rev. 2014, $38,823-864$. [CrossRef]

5. Albers, S.V.; Meyer, B.H. The archaeal cell envelope. Nat. Rev. Microbiol. 2011, 9, 414-426. [CrossRef] 
6. $\quad$ Egelseer, E.M.; Ilk, N.; Pum, D.; Messner, P.; Schäffer, C.; Schuster, B.; Sleytr, U.B. S-Layers, microbial, biotechnological applications. In Encyclopedia of Industrial Biotechnology: Bioprocess, Bioseparation, and Cell Technology; Flickinger, M.C., Ed.; John Wiley and Sons: Hoboken, NJ, USA, 2010; Volume 7, pp. 4424-4448.

7. Sleytr, U.B.; Schuster, B.; Egelseer, E.M.; Pum, D.; Horejs, C.M.; Tscheliessnig, R.; Ilk, N. Nanobiotechnology with S-Layer Proteins as Building Blocks. Mol. Assem. Nat. Eng. Syst. 2011, 103, 277-352. [CrossRef]

8. Ilk, N.; Egelseer, E.M.; Sleytr, U.B. S-layer fusion proteins-Construction principles and applications. Curr. Opin. Biotechnol. 2011, 22, 824-831. [CrossRef] [PubMed]

9. Sleytr, U.B.; Glauert, A.M. Analysis of Regular Arrays of Subunits on Bacterial Surfaces_Evidence for a Dynamic Process of Assembly. J. Ultrastruct. Res. 1975, 50, 103-116. [CrossRef]

10. Sleytr, U.B. Regular arrays of macromolecules on bacterial cell walls: Structure, chemistry, assembly, and function. Int. Rev. Cytol. 1978, 53, 1-62. [CrossRef]

11. Sleytr, U.B.; Messner, P.; Pum, D.; Sára, M. Crystalline bacterial cell surface layers (S layers): From supramolecular cell structure to biomimetics and nanotechnology. Angew. Chem. Int. Ed. 1999, 38, 1035-1054. [CrossRef]

12. Pavkov-Keller, T.; Howorka, S.; Keller, W. The structure of bacterial S-layer proteins. Prog. Mol. Biol. Transl. Sci. 2011, 103, 73-130. [CrossRef]

13. Khursigara, C.M.; Koval, S.F.; Moyles, D.M.; Harris, R.J. Inroads through the bacterial cell envelope: Seeing is believing. Can. J. Microbiol. 2018, 64, 601-617. [CrossRef] [PubMed]

14. Messner, P.; Schaffer, C.; Kosma, P. Bacterial Cell-Envelope Glycoconjugates. Adv. Carbohyd. Chem. Biochem. 2013, 69, 209-272. [CrossRef]

15. Schuster, B.; Sleytr, U.B. Relevance of glycosylation of S-layer proteins for cell surface properties. Acta Biomater. 2015, 19, 149-157. [CrossRef]

16. Schuster, B.; Sleytr, U.B. S-Layer Ultrafiltration Membranes. Membranes 2021, 11, 275. [CrossRef]

17. Watson, S.W.; Remsen, C.C. Cell Envelope of Nitrosocystis-Oceanus. J. Ultrastruct. Res. 1970, 33, 148-160. [CrossRef]

18. Beveridge, T.J.; Murray, R.G.E. Superficial Macromolecular Arrays on Cell-Wall of Spirillum-Putridiconchylium. J. Bacteriol. 1974, 119, 1019-1038. [CrossRef]

19. Suhr, M.; Lederer, F.L.; Gunther, T.J.; Raff, J.; Pollmann, K. Characterization of Three Different Unusual S-Layer Proteins from Viridibacillus arvi JG-B58 That Exhibits Two Super-Imposed S-Layer Proteins. PLoS ONE 2016, 11, e0156785. [CrossRef] [PubMed]

20. Sára, M.; Pum, D.; Küpcü, S.; Messner, P.; Sleytr, U.B. Isolation of two physiologically induced variant strains of Bacillus stearothermophilus NRS 2004/3a and characterization of their S-layer lattices. J. Bacteriol. 1994, 176, 848-860. [CrossRef] [PubMed]

21. Sára, M.; Kuen, B.; Mayer, H.F.; Mandl, F.; Schuster, K.C.; Sleytr, U.B. Dynamics in oxygen-induced changes in S-layer protein synthesis from Bacillus stearothermophilus PV72 and the S-layer-deficient variant T5 in continuous culture and studies of the cell wall composition. J. Bacteriol. 1996, 178, 2108-2117. [CrossRef]

22. Gambelli, L.; Meyer, B.H.; McLaren, M.; Sanders, K.; Quax, T.E.F.; Gold, V.A.M.; Albers, S.V.; Daum, B. Architecture and modular assembly of Sulfolobus S-layers revealed by electron cryotomography. Proc. Natl. Acad. Sci. USA 2019, 116, 25278-25286. [CrossRef]

23. Messner, P.; Pum, D.; Sleytr, U.B. Characterization of the ultrastructure and the self-assembly of the surface layer of Bacillus stearothermophilus strain NRS 2004/3a. J. Ultrastruct. Res. 1986, 97, 73-88. [CrossRef]

24. Sleytr, U.B.; Sára, M.; Küpcü, Z.; Messner, P. Structural and chemical characterization of S-layers of selected strains of Bacillus stearothermophilus and Desulfotomaculum nigrificans. Arch. Microbiol. 1986, 146, 19-24. [CrossRef] [PubMed]

25. Sára, M.; Küpcü, S.; Sleytr, U.B. Localization of the carbohydrate residue of the S-layer glycoprotein from Clostridium thermohydrosulfuricum L111-69. Arch. Microbiol. 1989, 151, 416-420. [CrossRef]

26. Sleytr, U.B.; Beveridge, T.J. Bacterial S-layers. Trends Microbiol. 1999, 7, 253-260. [CrossRef]

27. Sára, M. Conserved anchoring mechanisms between crystalline cell surface S-layer proteins and secondary cell wall polymers in Gram-positive bacteria. Trends Microbiol. 2001, 9, 47-49. [CrossRef]

28. Mader, C.; Huber, C.; Moll, D.; Sleytr, U.B.; Sara, M. Interaction of the crystalline bacterial cell surface layer protein SbsB and the secondary cell wall polymer of Geobacillus stearothermophilus PV72 assessed by real-time surface plasmon resonance biosensor technology. J. Bacteriol. 2004, 186, 1758-1768. [CrossRef] [PubMed]

29. Sara, M.; Sleytr, U.B. Charge distribution on the S layer of Bacillus stearothermophilus NRS 1536/3c and importance of charged groups for morphogenesis and function. J. Bacteriol. 1987, 169, 2804-2809. [CrossRef]

30. Gyorvary, E.; Schroedter, A.; Talapin, D.V.; Weller, H.; Pum, D.; Sleytr, U.B. Formation of nanoparticle arrays on S-layer protein lattices. J. Nanosci. Nanotechnol. 2004, 4, 115-120. [CrossRef] [PubMed]

31. Rothbauer, M.; Küpcü, S.; Sticker, D.; Sleytr, U.B.; Ertl, P. Exploitation of S-layer Anisotropy: pH-dependent Nanolayer Orientation for Cellular Micropatterning. ACS Nano 2013, 7, 8020-8030. [CrossRef] [PubMed]

32. Sleytr, U.B. Self-assembly of the hexagonally and tetragonally arranged subunits of bacterial surface layers and their reattachment to cell walls. J. Ultrastruct. Res. 1976, 55, 360-377. [CrossRef]

33. Sleytr, U.B. Heterologous reattachment of regular arrays of glycoproteins on bacterial surfaces. Nature 1975, 257, 400-402. [CrossRef]

34. Pum, D.; Sleytr, U.B. Reassembly of S-layer proteins. Nanotechnology 2014, 25, 312001. [CrossRef] 
35. Ucisik, M.H.; Sleytr, U.B.; Schuster, B. Emulsomes Meet S-layer Proteins: An Emerging Targeted Drug Delivery System. Curr. Pharm. Biotechnol. 2015, 16, 392-405. [CrossRef]

36. Pum, D.; Toca-Herrera, J.L.; Sleytr, U.B. S-Layer Protein Self-Assembly. Int. J. Mol. Sci. 2013, 14, 2484-2501. [CrossRef]

37. Schuster, B.; Gyorvary, E.; Pum, D.; Sleytr, U.B. Nanotechnology with S-layer proteins. Methods Mol. Biol. 2005, 300, 101-123. [CrossRef]

38. Fagan, R.P.; Fairweather, N.F. Biogenesis and functions of bacterial S-layers. Nat. Rev. Microbiol. 2014, 12, 211-222. [CrossRef] [PubMed]

39. Sleytr, U.B.; Messner, P. Self-assemblies of crystalline bacterial cell surface layers. In Electron Microscopy of Subcellular Dynamics; Plattner, H., Ed.; CRC Press: Boca Raton, FL, USA, 1989; pp. 13-31.

40. Jaenicke, R.; Welsch, R.; Sara, M.; Sleytr, U.B. Stability and self-assembly of the S-layer protein of the cell wall of Bacillus stearothermophilus. Biol. Chem. Hoppe Seyler 1985, 366, 663-670. [CrossRef] [PubMed]

41. Bobeth, M.; Blecha, A.; Bluher, A.; Mertig, M.; Korkmaz, N.; Ostermann, K.; Rodel, G.; Pompe, W. Formation of tubes during self-assembly of bacterial surface layers. Langmuir 2011, 27, 15102-15111. [CrossRef]

42. Chung, S.; Shin, S.H.; Bertozzi, C.R.; De Yoreo, J.J. Self-catalyzed growth of S layers via an amorphous-to-crystalline transition limited by folding kinetics. Proc. Natl. Acad. Sci. USA 2010, 107, 16536-16541. [CrossRef] [PubMed]

43. Shin, S.H.; Chung, S.; Sanii, B.; Comolli, L.R.; Bertozzi, C.R.; De Yoreo, J.J. Direct observation of kinetic traps associated with structural transformations leading to multiple pathways of S-layer assembly. Proc. Natl. Acad. Sci. USA 2012, 109, 12968-12973. [CrossRef]

44. Breitwieser, A.; Iturri, J.; Toca-Herrera, J.L.; Sleytr, U.B.; Pum, D. In Vitro Characterization of the Two-Stage Non-Classical Reassembly Pathway of S-Layers. Int. J. Mol. Sci. 2017, 18, 400. [CrossRef]

45. Stel, B.; Cometto, F.; Rad, B.; De Yoreo, J.J.; Lingenfelder, M. Dynamically resolved self-assembly of S-layer proteins on solid surfaces. Chem. Commun. 2018, 54, 10264-10267. [CrossRef] [PubMed]

46. Pum, D.; Sleytr, U.B. Large-scale reconstruction of crystalline bacterial surface layer proteins at the air-water interface and on lipids. Thin Solid Films 1994, 244, 882-886. [CrossRef]

47. Baranova, E.; Fronzes, R.; Garcia-Pino, A.; Van Gerven, N.; Papapostolou, D.; Pehau-Arnaudet, G.; Pardon, E.; Steyaert, J.; Howorka, S.; Remaut, H. SbsB structure and lattice reconstruction unveil $\mathrm{Ca}^{2+}$ triggered S-layer assembly. Nature 2012, 487, 119-122. [CrossRef]

48. Rad, B.; Haxton, T.K.; Shon, A.; Shin, S.H.; Whitelam, S.; Ajo-Franklin, C.M. Ion-specific control of the self-assembly dynamics of a nanostructured protein lattice. ACS Nano 2015, 9, 180-190. [CrossRef]

49. Comolli, L.R.; Siegerist, C.E.; Shin, S.H.; Bertozzi, C.; Regan, W.; Zettl, A.; De Yoreo, J. Conformational transitions at an S-Layer growing boundary resolved by Cryo-TEM. Angew. Chem. Int. Ed. 2013, 52, 4829-4832. [CrossRef]

50. Sleutel, M.; Van Driessche, A.E.S. Role of clusters in nonclassical nucleation and growth of protein crystals. Proc. Natl. Acad. Sci. USA 2014, 111, E546-E553. [CrossRef]

51. Györvary, E.S.; Stein, O.; Pum, D.; Sleytr, U.B. Self-assembly and recrystallization of bacterial S-layer proteins at silicon supports imaged in real time by atomic force microscopy. J. Microsc. 2003, 212, 300-306. [CrossRef]

52. Pum, D.; Sara, M.; Sleytr, U.B. Structure, surface charge, and self-assembly of the S-layer lattice from Bacillus coagulans E38-66. J. Bacteriol. 1989, 171, 5296-5303. [CrossRef]

53. Sara, M.; Sleytr, U.B. Relevance of charged groups for the integrity of the S-layer from Bacillus coagulans E38-66 and for molecular interactions. J. Bacteriol. 1993, 175, 2248-2254. [CrossRef]

54. Breitwieser, A.; Sleytr, U.B.; Pum, D. A New Method for Dispersing Pristine Carbon Nanotubes Using Regularly Arranged S-Layer Proteins. Nanomaterials 2021, 11, 1346. [CrossRef] [PubMed]

55. Breitwieser, A.; Pum, D.; Toca-Herrera, J.L.; Sleytr, U.B. Magnetic beads functionalized with recombinant S-layer protein exhibit high human IgG-binding and anti-fouling properties. Curr. Top. Pept. Protein Res. 2016, 17, 45-55.

56. Lopez, A.E.; Moreno-Flores, S.; Pum, D.; Sleytr, U.B.; Toca-Herrera, J.L. Surface dependence of protein nanocrystal formation. Small 2010, 6, 396-403. [CrossRef]

57. Moreno-Flores, S.; Kasry, A.; Butt, H.J.; Vavilala, C.; Schmittel, M.; Pum, D.; Sleytr, U.B.; Toca-Herrera, J.L. From native to non-native two-dimensional protein lattices through underlying hydrophilic/hydrophobic nanoprotrusions. Angew. Chem. Int. Ed. 2008, 47, 4707-4710. [CrossRef]

58. Lopez, A.E.; Pum, D.; Sleytr, U.B.; Toca-Herrera, J.L. Influence of surface chemistry and protein concentration on the adsorption rate and S-layer crystal formation. Phys. Chem. Chem. Phys. 2011, 13, 11905-11913. [CrossRef]

59. Küpcü, S.; Sára, M.; Sleytr, U.B. Liposomes coated with crystalline bacterial cell surface protein (S-layers) as immobilization structures for macromolecules. Biochim. Biophys. Acta 1995, 1235, 263-269. [CrossRef]

60. Ücisik, M.H.; Küpcü, S.; Debreczeny, M.; Schuster, B.; Sleytr, U.B. S-layer Coated Emulsomes as Potential Nanocarriers. Small 2013, 9, 2895-2904. [CrossRef]

61. Ucisik, M.H.; Küpcü, S.; Breitwieser, A.; Gelbmann, N.; Schuster, B.; Sleytr, U.B. S-layer fusion protein as a tool functionalizing emulsomes and CurcuEmulsomes for antibody binding and targeting. Colloid Surf. B 2015, 128, 132-139. [CrossRef] [PubMed]

62. Toca-Herrera, J.L.; Krastev, R.; Bosio, V.; Kupcu, S.; Pum, D.; Fery, A.; Sara, M.; Sleytr, U.B. Recrystallization of bacterial S-layers on flat polyelectrolyte surfaces and hollow polyelectrolyte capsules. Small 2005, 1, 339-348. [CrossRef] [PubMed]

63. Schuster, B.; Pum, D.; Sleytr, U.B. S-layer stabilized lipid membranes. Biointerphases 2008, 3, FA3. [CrossRef] 
64. Holser, W.T. Point Groups and Plane Groups in a Two-Sided Plane and their Subgroups. Z. Krist. Cryst. Mater. 1958, 110, $266-281$. [CrossRef]

65. Kopský, V.; Litvin, D.B. (Eds.) International Tables for Crystallography: Volume E: Subperiodic Groups, 5th ed.; The International Union of Crystallography; John Wiley\&Sons, Ltd.: Chichester, UK, 2006.

66. Baumeister, W.; Engelhardt, H. Three-dimensional structure of bacterial surface layers. In Electron Microscopy of Proteins; Harris, J.R., Horne, R.W., Eds.; Academic Press, Inc.: London, UK, 1987; Volume 6, pp. 109-154.

67. Hovmoller, S.; Sjogren, A.; Wang, D.N. The structure of crystalline bacterial surface layers. Prog. Biophys. Mol. Biol. 1988, 51, 131-163. [CrossRef]

68. Amos, L.A.; Henderson, R.; Unwin, P.N.T. Three-dimensional structure determination by electron microscopy of two-dimensional crystals. Prog. Biophys. Mol. Biol. 1982, 39, 183-231. [CrossRef]

69. Messner, P.; Pum, D.; Sára, M.; Stetter, K.O.; Sleytr, U.B. Ultrastructure of the cell envelope of the archaebacteria Thermoproteus tenax and Thermoproteus neutrophilus. J. Bacteriol. 1986, 166, 1046-1054. [CrossRef]

70. Saxton, W.O.; Baumeister, W. Principles of organization in S layers. J. Mol. Biol. 1986, 187, 251-253. [CrossRef]

71. Baumeister, W.; Wildhaber, I.; Phipps, B.M. Principles of organization in eubacterial and archaebacterial surface proteins. Can. J. Microbiol. 1989, 35, 215-227. [CrossRef] [PubMed]

72. Pavkov, T.; Egelseer, E.M.; Tesarz, M.; Svergun, D.I.; Sleytr, U.B.; Keller, W. The structure and binding behavior of the bacterial cell surface layer protein SbsC. Structure 2008, 16, 1226-1237. [CrossRef] [PubMed]

73. Fagan, R.P.; Albesa-Jove, D.; Qazi, O.; Svergun, D.I.; Brown, K.A.; Fairweather, N.F. Structural insights into the molecular organization of the S-layer from Clostridium difficile. Mol. Microbiol. 2009, 71, 1308-1822. [CrossRef] [PubMed]

74. Ethordic, A.; Egelseer, E.M.; Tesarz, M.; Sleytr, U.B.; Keller, W.; Pavkov-Keller, T. Crystallization of domains involved in self-assembly of the S-layer protein SbsC. Acta Crystallogr. Sect. F Struct. Biol. Cryst. Commun. 2012, 68, 1511-1514. [CrossRef]

75. Jones, M.D.; Chan, A.C.K.; Nomellini, J.F.; Murphy, M.E.P.; Smit, J. Surface-layer protein from Caulobacter crescentus: Expression, purification and X-ray crystallographic analysis. Acta Crystallogr. Sect. F Struct. Biol. Commun. 2016, 72, 677-680. [CrossRef]

76. Liu, J.; Falke, S.; Drobot, B.; Oberthuer, D.; Kikhney, A.; Guenther, T.; Fahmy, K.; Svergun, D.; Betzel, C.; Raff, J. Analysis of self-assembly of S-layer protein slp-B53 from Lysinibacillus sphaericus. Eur. Biophys. J. 2017, 46, 77-89. [CrossRef] [PubMed]

77. Bharat, T.A.M.; Kureisaite-Ciziene, D.; Hardy, G.G.; Yu, E.W.; Devant, J.M.; Hagen, W.J.H.; Brun, Y.V.; Briggs, J.A.G.; Lowe, J. Structure of the hexagonal surface layer on Caulobacter crescentus cells. Nat. Microbiol. 2017, 2, 17059. [CrossRef] [PubMed]

78. Bradshaw, W.J.; Roberts, A.K.; Shone, C.C.; Acharya, K.R. The structure of the S-layer of Clostridium difficile. J. Cell Commun. Signal. 2018, 12, 319-331. [CrossRef] [PubMed]

79. von Kügelgen, A.; Tang, H.; Hardy, G.G.; Kureisaite-Ciziene, D.; Brun, Y.V.; Stansfeld, P.J.; Robinson, C.V.; Bharat, T.A.M. In Situ Structure of an Intact Lipopolysaccharide-Bound Bacterial Surface Layer. Cell 2020, 180, 348-358.e315. [CrossRef]

80. Schur, F.K.M. Toward high-resolution in situ structural biology with cryo-electron tomography and subtomogram averaging. Curr. Opin. Struc. Biol. 2019, 58, 1-9. [CrossRef]

81. Wan, W.; Briggs, J.A.G. Cryo-Electron Tomography and Subtomogram Averaging. Methods Enzymol. 2016, 579, 329-367. [CrossRef]

82. Crowther, R.A.; Sleytr, U.B. An analysis of the fine structure of the surface layer from two strains of clostridia, including correction for distorted images. J. Ultrastruct. Res. 1977, 58, 41-49. [CrossRef]

83. Saxton, W.O.; Baumeister, W. The correlation averaging of a regularly arranged bacterial cell envelope protein. J. Microsc. 1982, 127, 127-138. [CrossRef] [PubMed]

84. Pum, D.; Messner, P.; Sleytr, U.B. Role of the S layer in morphogenesis and cell division of the Archaebacterium Methanocorpusculum sinense. J. Bacteriol. 1991, 173, 6865-6873. [CrossRef]

85. Harris, W.F. Disclinations. Sci. Am. 1977, 237, 130-145. [CrossRef]

86. Harris, W.F.; Scriven, L.E. Function of Dislocations in Cell Walls and Membranes. Nature 1970, 228, 827-829. [CrossRef] [PubMed]

87. Harris, W.F. Negative wedge disclinations of rotation $2 \pi$ radians and topological changes of membranous systems. Philos. Mag. $A$ J. Theor. Exp. Appl. Phys. 1975, 32, 37-41. [CrossRef]

88. Caspar, D.L.D.; Klug, A. Physical principles in the construction of regular viruses. Cold Spring Harb. Symp. Quant. Biol. 1962, 27, 1-24. [CrossRef]

89. Harris, W.F.; Scriven, L.E. Intrinsic Disclinations as Dislocation Sources and Sinks in Surface Crystals. J. Appl. Phys. 1971, 42, 3309-3312. [CrossRef]

90. DeWit, A.; Borckmans, P.; Dewel, G. Twist grain boundaries in three-dimensional lamellar Turing structures. Proc. Natl. Acad. Sci. USA 1997, 94, 12765-12768. [CrossRef]

91. Ionov, R.; El-Abed, A.; Angelova, A.; Goldmann, M.; Peretti, P. Asymmetrical ion-channel model inferred from two-dimensional crystallization of a peptide antibiotic. Biophys. J. 2000, 78, 3026-3035. [CrossRef]

92. Pum, D.; Sleytr, U.B. Anisotropic crystal growth of the S-layer of Bacillus sphaericus CCM 2177 at the air/water interface. Colloids Surf. A 1995, 102, 99-104. [CrossRef]

93. Huber, C.; Ilk, N.; Rünzler, D.; Egelseer, E.M.; Weigert, S.; Sleytr, U.B.; Sára, M. The three S-layer-like homology motifs of the S-layer protein SbpA of Bacillus sphaericus CCM 2177 are not sufficient for binding to the pyruvylated secondary cell wall polymer. Mol. Microbiol. 2005, 55, 197-205. [CrossRef]

94. Moll, D.; Huber, C.; Schlegel, B.; Pum, D.; Sleytr, U.B.; Sara, M. S-layer-streptavidin fusion proteins as template for nanopatterned molecular arrays. Proc. Natl. Acad. Sci. USA 2002, 99, 14646-14651. [CrossRef] 
95. Sára, M.; Sleytr, U.B. Molecular sieving through S-layers of Bacillus stearothermophilus strains. J. Bacteriol. 1987, 169, 4092-4098. [CrossRef]

96. Sleytr, U.B.; Sara, M. Ultrafiltration Membranes with Uniform Pores from Crystalline Bacterial-Cell Envelope Layers. Appl. Microbiol. Biotechnol. 1986, 25, 83-90. [CrossRef]

97. Sara, M.; Manigley, C.; Wolf, G.; Sleytr, U.B. Isoporous Ultrafiltration Membranes from Bacterial-Cell Envelope Layers. J. Membr. Sci. 1988, 36, 179-186. [CrossRef]

98. Kupcu, S.; Sara, M.; Sleytr, U.B. Influence of Covalent Attachment of Low-Molecular-Weight Substances on the Rejection and Adsorption Properties of Crystalline Proteinaceous Ultrafiltration Membranes. Desalination 1993, 90, 65-76. [CrossRef]

99. Sára, M.; Sleytr, U.B. Production and characteristics of ultrafiltration membranes with uniform pores from two-dimensional arrays of proteins. J. Membr. Sci. 1987, 33, 27-49. [CrossRef]

100. Manea, F.; Garda, V.G.; Rad, B.; Ajo-Franklin, C.M. Programmable assembly of 2D crystalline protein arrays into covalently stacked 3D bionanomaterials. Biotechnol. Bioeng. 2020, 117, 912-923. [CrossRef]

101. Charrier, M.; Li, D.; Mann, V.R.; Yun, L.; Jani, S.; Rad, B.; Cohen, B.E.; Ashby, P.D.; Ryan, K.R.; Ajo-Franklin, C.M. Engineering the S-Layer of Caulobacter crescentus as a Foundation for Stable, High-Density, 2D Living Materials. ACS Synth. Biol. 2019, 8 , 181-190. [CrossRef]

102. Raff, J.; Matys, S.; Suhr, M.; Vogel, M.; Günther, T.; Pollmann, K. S-Layer-Based Nanocomposites for Industrial Applications. In Protein-Based Engineered Nanostructure; Cortajarena, A.L., Grove, T.Z., Eds.; Springer International Publishing: Cham, Switzerland, 2016; pp. 245-279.

103. Schuster, B.; Sleytr, U. Biomimetic S-layer-Lipid self-assemblies as platform for membrane-active peptides and proteins. Eur. Biophys. J. 2015, 44, S98.

104. Pum, D.; Sleytr, U.B. S-layer proteins for assembling ordered nanoparticle arrays. In Nanobioelectronics—For Electronics, Biology, and Medicine; Offenhäuser, A., Rinaldi, R., Eds.; Springer: New York, NY, USA, 2009; pp. 167-180.

105. Völlenkle, C.; Weigert, S.; Ilk, N.; Egelseer, E.; Weber, V.; Loth, F.; Falkenhagen, D.; Sleytr, U.B.; Sara, M. Construction of a functional S-layer fusion protein comprising an immunoglobulin G-binding domain for development of specific adsorbents for extracorporeal blood purification. Appl. Environ. Microbiol. 2004, 70, 1514-1521. [CrossRef]

106. Schuster, B. S-Layer Protein-Based Biosensors. Biosensors 2018, 8, 40. [CrossRef]

107. Rothbauer, M.; Ertl, P.; Theiler, B.A.; Schlager, M.; Sleytr, U.B.; Kupcu, S. Anisotropic Crystalline Protein Nanolayers as MultiFunctional Biointerface for Patterned Co-Cultures of Adherent and Non-Adherent Cells in Microfluidic Devices. Adv. Mater. Interfaces 2015, 2. [CrossRef]

108. Oatley, P.; Kirk, J.A.; Ma, S.W.; Jones, S.; Fagan, R.P. Spatial organization of Clostridium difficile S-layer biogenesis. Sci. Rep. 2020, 10. [CrossRef] 